American Journal of Pharmaceutical Education 2019; 83 (7) Article 7021.

\title{
RESEARCH
}

\section{Implementation, Revisions, and Student Perceptions of a Pre-Matriculation Program in a School of Pharmacy}

\author{
Eytan A. Klausner, PhD, ${ }^{a}$ Erica L. Rowe, PhD, ${ }^{a}$ Beverly S. Hamilton, PhD, ${ }^{\text {a,b }}$ Karen S. Mark, PhD \\ ${ }^{a}$ South College, School of Pharmacy, Knoxville, Tennessee \\ ${ }^{\mathrm{b}}$ Lincoln Memorial University, Harrogate, Tennessee
}

Submitted February 15, 2018; accepted July 9, 2018; published September 2019.

Objective. To characterize the development, revision, and student perceptions of a pre-matriculation program entitled Pharmacy Readiness and Enrichment Program (PREP) in a school of pharmacy.

Methods. The program was first implemented in June 2013 for the incoming class of 2016. The main components of PREP were curriculum and scientific content review, professionalism, time management, critical thinking, and personal interactions. Entering student pharmacists were surveyed immediately and six or more months after PREP concluded. Statistical analysis was performed to determine if participation in PREP affected students' academic performance.

Results. Student perceptions regarding the program and its components were favorable immediately after PREP but less favorable six or more months later. Statistical analysis showed that students who completed PREP had significantly higher cumulative grade point average (GPA) in pharmacy year one and year two.

Conclusion. It is possible to implement a two-day pre-matriculation program with a wide range of components and deliver it prior to the start of the first professional year. It is also possible to deliver some PREP components during the first professional year rather than prior to matriculation into the program. The PREP may serve as a model for other schools of pharmacy that are considering the implementation of a pre-matriculation program, or that have a pre-matriculation program in place and are seeking to modify or update their program.

Keywords: pre-matriculation program, pharmacy accelerated program, 2016 ACPE standards, orientation program, pharmacy bridging course

\section{INTRODUCTION}

The South College School of Pharmacy (SCSOP) began its three-year accelerated Doctor of Pharmacy (PharmD) program with the matriculation of its first class in 2012. As the first two cohorts entered the program, the faculty and administration noticed a growing diversity in the students' educational backgrounds and experiences. This prompted the administration and faculty to design a pre-matriculation program (the Pharmacy Readiness and Enrichment Program (PREP)) to facilitate the transition of students from undergraduate coursework into a professional pharmacy program. As a result, PREP was implemented beginning with the third cohort of students who matriculated in 2013 (class of 2016).

The broad diversity of the student population with regard to educational rigor and background, professionalism and ethics, and prior pharmacy exposure is not

Corresponding Author: Eytan A. Klausner, South College, School of Pharmacy, Knoxville, TN 37922. Tel: 865-2885835. E-mail: eklausner@south.edu unique to SCSOP. Some of the changes that schools of pharmacy see in their student populations is, in part, associated with the decreased number of pharmacy school applicants nationwide coupled with a concurrent increase in the number of schools of pharmacy. ${ }^{1-5}$ In addition, there may be cultural changes that affect the behavior of student pharmacists during their professional program such as feelings of academic entitlement, and students' attitude toward social media professionalism. ${ }^{6-8}$

To facilitate transition into the pharmacy program, some schools of pharmacy offer their incoming students pre-matriculation programs that typically range from several days to a few weeks and cover a variety of topics. ${ }^{9}$ The following are examples of pre-matriculation programs that are described on the respective schools' websites. The pre-matriculation program offered by Xavier University of Louisiana College of Pharmacy lasts four weeks and covers ethics, cultural competency training, and didactic teaching of biomedical immunology, human anatomy and physiology, pharmacy calculations, and 


\section{American Journal of Pharmaceutical Education 2019; 83 (7) Article 7021.}

pharmaceutical biochemistry. ${ }^{10}$ The pre-matriculation program offered by Creighton University School of Pharmacy and Health Professions lasts eight weeks and focuses on reinforcing basic writing skills, as well as providing a review/enrichment in coursework areas such as biology, chemistry, mathematics, physics, and cultural awareness. ${ }^{11}$ The Native American Center of Excellence at University of Montana Skaggs School of Pharmacy offers an intensive, four-week course geared toward preparing American Indian/Alaska natives and other minority students for the professionalism, leadership, and academic demands of the pharmacy school curriculum. ${ }^{12}$ Their sessions cover a range of topics in pharmacy including pharmaceutical biochemistry, pharmaceutics, calculations, pharmacology, pharmacy practice, and American Indian health issues. Northeast Ohio Medical University offers an online pre-matriculation program that covers learning strategies, cell biology, anatomy, and mindfulness. ${ }^{13}$ This program starts prior to student matriculation and extends into the professional pharmacy program. ${ }^{14}$

Some schools may have implemented and/or altered their pre-matriculation programs in recent years to address and prepare for ACPE 2016 Standards which place more emphasis on learner outcomes related to professionalism and affective domains necessary in interprofessional health care. ${ }^{15}$ The University of Iowa implemented changes in their curriculum in 2015; at least partly to address ACPE Standards 2016. One of those changes involved the initiation of a program that aims to create a smooth transition into student life. ${ }^{16}$ This program includes a full week, prematriculation program prior to the start of the first professional year followed by a one-credit course during the first semester of the first professional year. ${ }^{17}$

Similar to these other pharmacy programs, the underlying rationale for the implementation of PREP at SCSOP was to support undergraduate students entering a professional pharmacy program in becoming more successful in attaining programmatic outcomes. After the first delivery of PREP, changes were made to the program that prompted this research project.

In this study we describe the SCSOP pre-matriculation program and its development process, describe student perceptions of the program and its individual components, identify measurable outcomes of academic performance to support implementation of the pre-matriculation program, and outline a successful pre-matriculation program model that could be used by other schools of pharmacy.

\section{METHODS}

The inaugural PREP was delivered in 2013, and included "pearls for success," which were provided by second-year student pharmacists, and a team-building exercise. The various components of PREP that were delivered at SCSOP are listed in Table 1. These components consisted primarily of core scientific topics, cognitive and affective domain topics, professionalism and ethics, student support services, and personal interaction sessions, all of which were designed to facilitate student transition into the professional pharmacy program.

The PREP was delivered immediately following orientation and before the start of summer (first) quarter in the first professional year of the pharmacy program. All PREP sessions were delivered by faculty or staff members with expertise in the relevant areas. Although attendance was not mandatory, it was conveyed to the students that attendance was expected as a sign of professionalism and that the sessions served as a supplement to the curriculum. Active student engagement was encouraged whenever possible.

Each year after the delivery of PREP, the student survey results, faculty feedback, and guidance documents from ACPE were used to implement appropriate revisions to PREP for its continuous quality improvement. Substantial changes were made in the delivery of PREP to the Class of 2018 (Table 1). Faculty feedback and input regarding student professionalism, preparedness for clinical rotations, and other related concerns provided the impetus for these changes. This PREP was extended ( 2.5 days) and included seven new sessions: overview of the curriculum; professionalism; avoiding plagiarism; time management and organization; skills for case studies; a session for accessing, using, and citing resources; and a mentor-mentee social. The class of 2018 PREP also retained key sessions that appeared in previous PREPs: Microbiology, Pharmacy Academic Support Services, stress management, and Q\&A with upperclassmen.

The delivery of PREP to the class of 2019 was different in part because of the SCSOP's reaction to the then new ACPE 2016 standards, and the timeframe available prior to the start of the first professional year. Therefore, sessions identified as necessary for entering students were delivered in the main program during the two days prior to the start of the first quarter. Some sessions were strategically placed throughout the first academic year in order to review or prepare the students for content in a course that they would be exposed to in an upcoming quarter. These sessions included: stress management, Pharmacy Academic Support Services, the South College Writing Lab, accessing and citing resources, pharmacy calculations, and skills for case studies.

While PREP underwent some type of change during each of the four years, there were some consistent components that were used to form a framework for the PREP 
American Journal of Pharmaceutical Education 2019; 83 (7) Article 7021.

Table 1. Components of a Pre-Matriculation Program Held for Undergraduate Students Entitled the Pharmacy Readiness and Enrichment Program

\begin{tabular}{|c|c|c|c|c|c|}
\hline & & $\begin{array}{c}\text { Class of } \\
2016 \\
\end{array}$ & $\begin{array}{c}\text { Class of } \\
2017 \\
\end{array}$ & $\begin{array}{c}\text { Class of } \\
2018 \\
\end{array}$ & $\begin{array}{c}\text { Class of } \\
2019 \\
\end{array}$ \\
\hline Year administered, in June & & 2013 & 2014 & 2015 & 2016 \\
\hline Length of PREP & & 2 days & 1.5 day & 2.5 days & 2 days $^{a}$ \\
\hline Topic & PREP Component & & & & \\
\hline \multirow[t]{8}{*}{ Curriculum/scientific content } & Overview of curriculum & $\mathrm{N}$ & $\mathrm{N}$ & $\mathrm{Y}^{\mathrm{b}}$ & $\mathrm{Y}$ \\
\hline & Scientific review: Chemistry/Organic chemistry & $\mathrm{Y}$ & Y & $\mathrm{Y}$ & $\mathrm{Y}$ \\
\hline & Scientific review: Anatomy/physiology & Y & $\mathrm{Y}$ & Y & $\mathrm{Y}$ \\
\hline & Scientific review: Immunology & $\mathrm{N}$ & $\mathrm{Y}^{\mathrm{b}}$ & $\mathrm{N}$ & $\mathrm{N}$ \\
\hline & Scientific review: Microbiology & Y & $\mathrm{N}$ & Y & $\mathrm{N}$ \\
\hline & Scientific review: Pharmacy calculations & Y & $\mathrm{N}$ & Y & YL \\
\hline & Scientific review: Medical terminology & Y & $\mathrm{N}$ & $\mathrm{Y}$ & $\mathrm{Y}$ \\
\hline & Skills for solving case studies & $\mathrm{N}$ & $\mathrm{N}$ & $Y^{b}$ & YL \\
\hline \multirow[t]{3}{*}{ Cognitive and affective skills } & Critical thinking/study skills & Y & Y & $\mathrm{Y}$ & $\mathrm{Y}$ \\
\hline & Time management \& organization & $\mathrm{N}$ & $\mathrm{N}$ & $Y^{b}$ & $\mathrm{Y}$ \\
\hline & Stress management & $\mathrm{N}$ & $\mathrm{Y}^{\mathrm{b}}$ & $\mathrm{Y}$ & YL \\
\hline \multirow[t]{4}{*}{ Professionalism \& ethics } & Professionalism & $\mathrm{N}$ & $\mathrm{N}$ & $\mathrm{Y}^{\mathrm{b}}$ & $\mathrm{Y}$ \\
\hline & Identifying and avoiding plagiarism & $\mathrm{N}$ & $\mathrm{N}$ & $\mathrm{Y}^{\mathrm{b}}$ & $\mathrm{Y}$ \\
\hline & Cultural diversity and awareness & $\mathrm{N}$ & $\mathrm{N}$ & $\mathrm{N}$ & $\mathrm{Y}^{\mathrm{b}}$ \\
\hline & Accessing, using, and citing resources & $\mathrm{N}$ & $\mathrm{N}$ & $\mathrm{Y}^{\mathrm{b}}$ & YL \\
\hline \multirow[t]{3}{*}{ Personal interactions } & Mentor (faculty)/mentee (student) social & $\mathrm{N}$ & $\mathrm{N}$ & $\mathrm{Y}^{\mathrm{b}}$ & $\mathrm{Y}$ \\
\hline & Q\&A with upperclassmen & $\mathrm{Y}$ & $\mathrm{N}$ & $\mathrm{Y}$ & $\mathrm{Y}$ \\
\hline & Team work/building & $\mathrm{Y}$ & & & \\
\hline \multirow[t]{2}{*}{ Student support services } & Pharmacy Academic Support Services & $\mathrm{N}$ & $Y^{b}$ & Y & YL \\
\hline & Writing Lab & $\mathrm{N}$ & $\mathrm{N}$ & $\mathrm{N}$ & $\mathrm{YL}^{\mathrm{b}}$ \\
\hline Total number of sessions & & 8 & 6 & 16 & 17 \\
\hline
\end{tabular}

model as well as the addition of sessions that target the affective domains, which are critical for interprofessional health care providers. All PREPs administered had at least three scientific content review sessions and a session about critical thinking. Sessions that appeared most frequently, in at least three of the PREPs, were chemistry/ organic chemistry, anatomy/physiology, medical terminology, Q\&A with upperclassmen, pharmacy calculations, stress management, and Pharmacy Academic Support Services.

To assess the success of the PREP, this study examined the following data for student pharmacists enrolled at SCSOP: entering cumulative GPA and Pharmacy College Admissions Test (PCAT) records submitted to the Pharmacy College Application Service (PharmCAS), academic records during the first and second professional years in the pharmacy program at SCSOP, and PREP survey results regarding student perceptions of the respective PREP components and the program overall. Admissions data and academic performance data according to cohorts are presented in Table 2.

The study protocol was approved by the South College Institutional Review Board (IRB). Each year, all enrolled students were invited to participate in the study, and those who were not able or willing to provide consent were excluded. The study population included students from the classes of 2015, 2017, 2018, and 2019. Records of consent to use student academic records were not obtained for the class of 2016; therefore, 2016 student perceptions and academic data are not represented in the Results section. Students in the class of 2015 served as the control group for this study since PREP was implemented after they had matriculated into the professional pharmacy curriculum at SCSOP.

To assess the effectiveness of the various components of PREP that were delivered, incoming student pharmacists were surveyed immediately after completion of PREP sessions, prior to the start of the first 


\section{American Journal of Pharmaceutical Education 2019; 83 (7) Article 7021.}

Table 2. Admissions Data and Academic Performance of Students who Participated in a PREP

\begin{tabular}{lcccccc}
\hline Cohort & $\begin{array}{c}\text { Size } \\
(\mathbf{n})^{\mathbf{a}}\end{array}$ & $\begin{array}{c}\text { PREP } \\
\text { Administration }\end{array}$ & $\begin{array}{c}\text { Entering GPA, } \\
\text { Mean (SD) }\end{array}$ & $\begin{array}{c}\text { PCAT Composite, } \\
\text { Mean (SD) }\end{array}$ & $\begin{array}{c}\text { Year 1 GPA, } \\
\text { Mean (SD) }\end{array}$ & $\begin{array}{c}\text { Year 2 GPA, } \\
\text { Mean (SD) }\end{array}$ \\
\hline Class of 2015 & 61 & $\mathrm{~N}$ & $3.00(0.36)$ & $40.7(15.8)$ & $3.05(0.36)$ & $3.18(0.32)$ \\
Class of 2017 & 80 & Y & $2.97(0.43)$ & $45.3(20.1)$ & $3.35(0.38)^{\mathrm{b}}$ & $3.35(0.31)^{\mathrm{c}}$ \\
Class of 2018 & 87 & Y & $2.95(0.41)$ & $40.2(19.6)$ & $3.26(0.40)^{\mathrm{c}}$ & $3.40(0.29)^{\mathrm{b}}$ \\
Class of 2019 & 70 & Y & $2.90(0.48)$ & $44.3(21.3)$ & $3.37(0.38)^{\mathrm{b}}$ & N/A \\
\hline
\end{tabular}

Abbreviations: $\mathrm{PREP}=$ pharmacy readiness and enrichment program, GPA= grade point average, $\mathrm{PCAT}=$ pharmacy college admissions test

${ }^{\text {a }}$ Includes only students who gave consent to use their academic data

${ }^{\mathrm{b}}$ Statistically different from class of 2015, $p<.001$

${ }^{c}$ Statistically different from class of $2015, p<.01$

quarter. The surveys were designed to determine students' satisfaction with the overall quality of the prematriculation program and the various components delivered to the respective cohorts. A 5-point Likert scale $(1=$ poor and $5=$ excellent $)$ was used to assess the overall quality of the program. The surveys used to assess the various PREP components used either a 4- or 5-point Likert scale. In the surveys administered immediately after PREP, the students were asked to respond to statements in relation to each session such as, "This session was helpful to me as a new student," and "Information was presented in a concise and easy to follow manner." Upon further consideration, we theorized that students might have a broader perspective about the benefits of PREP later during their first year. Therefore, an additional survey was administered to the classes of 2018 and 2019 in the secondhalf of their first professional year in the pharmacy program. In the surveys administered six or more months after PREP, students were asked to respond to statements related to each session such as "This session helped me to better navigate in the professional pharmacy program," and "This session helped me throughout the first-year curriculum." Basic information regarding the various surveys is shown in Table 3. Surveys were administered to the entire class as one large group, with the exception of the survey administered to the class of 2018 6-12 months after PREP that was administered in sections as part of focus groups.

All student-related data were de-identified prior to statistical analyses. Positive student perceptions (eg, good, very good, and excellent) were grouped together and summed. When appropriate, descriptive statistics were generated on positive student perceptions regarding the individual PREP sessions or PREP in its entirety. Analyses to identify differences between positive student perceptions of scientific sessions versus non-scientific sessions were conducted using the Mann-Whitney test. Analyses to identify differences between student perceptions regarding specific PREP sessions in surveys administered immediately after PREP in comparison to surveys administered six or more months after PREP were conducted with two-tailed, paired $t$ tests.

The outcomes measured were students' cumulative GPA at the end of the first and the second professional year in the pharmacy program. The first year GPAs of the classes of 2017, 2018, and 2019 were compared to the first-year GPA of the control group (class of 2015). The second-year GPAs for the classes of 2017 and 2018 were compared to the second year GPA for the control group. The composite PCAT scores for all cohorts of the classes of 2017, 2018, and 2019 were compared to those of the control.

One-way analysis of variance (ANOVA) was performed to identify differences in first professional year GPA, second professional year GPA, entering cumulative GPA, and composite PCAT scores between different cohorts. In cases where ANOVA showed statistical differences, a subsequent Tukey-Kramer multiple comparisons test was performed, and the data for the class of 2015 were used as a control. In the data analysis, statistical significance was set at $p<.05$; and, data are presented

Table 3. Survey Responses of Students Who Participated in a PREP

\begin{tabular}{llccc}
\hline Class Surveyed & Time of Survey Administration & Students, No. & Class Size, No. & Response Rate, \% \\
\hline Class of 2017 & Immediately after PREP, June 2014 & 94 & 104 & 90 \\
Class of 2018 & Immediately after PREP, June 2015 & 83 & 93 & 89 \\
& 6-12 months after PREP, 2016 ${ }^{\text {a }}$ & 53 & 89 & 60 \\
Class of 2019 & Immediately after PREP, July 2016 & 80 & 81 & 99 \\
& 6 months after PREP, December 2016 & 75 & 79 & 95 \\
\hline
\end{tabular}

Abbreviation: $\mathrm{PREP}=$ pharmacy readiness and enrichment program

${ }^{a}$ This survey was administered in sections as part of focus groups held 6-12 months after PREP 


\section{American Journal of Pharmaceutical Education 2019; 83 (7) Article 7021.}

as mean and standard deviation. The software used for statistical analyses was GraphPad InStat (GraphPad Software, La Jolla, CA).

\section{RESULTS}

Information regarding the number of students who participated in the surveys and their response rates is shown in Table 3. Most surveys had a response rate of at least $89 \%$. The results showed that immediately after completing PREP, a strong majority of students had a positive perception of the overall PREP experience $(98 \%, 93 \%$, and $88 \%$ for the Classes of 2017, 2018, and 2019, respectively). The PREP delivered to the class of 2017 was the shortest and had the fewest number of sessions (Table 1). The survey administered to the class of 2017 immediately after PREP showed that the average positive student perceptions for the various sessions was $96 \%(\mathrm{SD}=6 \%)$. For brevity, there is no further description of student perceptions from the class of 2017 regarding individual PREP sessions.

Student perceptions regarding the different components of the class of 2018 PREP, surveyed immediately after or 6-12 months after its completion, are presented in Table 4 . The average positive student perceptions for 10 individual PREP sessions that appeared both in the survey administered immediately after PREP and the survey administered 6-12 months after PREP were 93\% (SD=5) and $51 \%(\mathrm{SD}=7 \%)$, respectively. This finding reflects a decline $(p<.001)$ in the positivity of the student perceptions regarding those 10 PREP sessions from the survey administered immediately after PREP to the survey administered 6-12 months after PREP (Table 4). The average decline in the sum of positive student perceptions, for the sessions that appeared in both surveys, was $42 \%$ $(\mathrm{SD}=9)$.

Six to 12 months after the class of 2018 completed PREP, approximately $57 \%(\mathrm{SD}=5 \%)$ of the students had a positive perception of the scientific sessions and $45 \%$ $(\mathrm{SD}=3 \%)$ had a positive perception of the non-scientific sessions (Table 4). Statistical analysis showed that students perceptions regarding the scientific sessions were more positive in comparison to the perceptions regarding the non-scientific sessions $(p<.05)$. This difference was not seen in the survey results obtained immediately after these students completed the PREP.

Student perceptions regarding the different components of the class of 2019 PREP, surveyed immediately after or six months after its completion, are presented in Table 4: the average positive student perceptions for six individual PREP sessions that appeared in both surveys was $89 \%(\mathrm{SD}=9 \%)$ and $76 \%(\mathrm{SD}=9 \%)$, respectively.
This finding reflects a decline $(p<.01)$ in the positivity of student perceptions regarding those six PREP sessions from the survey administered immediately after PREP to the survey administered six months after PREP (Table 4). The average decline in the sum of positive student perceptions for the sessions that appeared in both surveys was $14 \%(\mathrm{SD}=7)$. In most surveys, the sum of the positive student perceptions showed that the chemistry/organic chemistry sessions consistently scored the lowest or the second lowest compared to other PREP sessions (Table $4)$.

Another objective of this study was to identify measurable outcomes of academic performance to support implementation of the pre-matriculation program. Admissions data and academic performance of students according to cohort for the four cohorts of SCSOP students are shown in Table 2. Statistical analysis of the academic metrics showed no significant difference in their entering cumulative GPA and composite PCAT scores. However, there were significant differences in the measured student learner outcomes of first and second professional year GPA among the four cohorts (ie, the class of 2015 versus the classes of 2017, 2018, and 2019). When performing ANOVA to compare the outcomes, first professional year GPA, a significant difference was found between the four cohorts, $p<.001$. Post-hoc analysis (Tukey-Kramer multiple comparisons test) showed significant differences between the first year GPA of the class of 2015 and that of the class of 2017 $(p<.001)$, the class of $2018(p<.01)$, and the class of 2019 $(p<.001)$. However, no significant difference was found between the first year GPA of the class of 2017 and that of the class of 2018, between the class of 2017 and the class of 2019, or between the class of 2018 and the class of 2019. Moreover, ANOVA of second-year GPA showed similar results with significant differences found between the three cohorts of students $(p<.001)$. Post-hoc analysis (Tukey-Kramer multiple comparisons test) indicated that there was a significant difference between the second year GPA of the class of 2015 and that of the class of 2017 $(p<.01)$ and the class of $2018(p<.001)$. However, there was no difference between the second year GPA of the class of 2017 and the class of 2018.

The fourth objective of this project was to outline a successful pre-matriculation program model that could be used by other schools of pharmacy. The framework for a pre-matriculation model was gathered as part of the development process of the SCSOP PREP as well as a literature review. ${ }^{9,18}$ These sessions are listed in Table 5 according to topic areas and can be used as a pre-matriculation program model by other schools of pharmacy. 


\section{American Journal of Pharmaceutical Education 2019; 83 (7) Article 7021.}

Table 4. Percentage of Students Responding Positively to Content Presented in the Pharmacy Readiness and Enrichment Program Prior to and After Starting a Doctor of Pharmacy Curriculum ${ }^{\mathrm{a}}$

\begin{tabular}{|c|c|c|c|c|}
\hline \multirow[b]{2}{*}{ Component } & \multicolumn{2}{|c|}{$\begin{array}{c}\text { Class of } 2018 \\
\text { Positive Survey Responses, }{ }^{\text {b,c }} \%\end{array}$} & \multicolumn{2}{|c|}{$\begin{array}{c}\text { Class of 2019, } \\
\text { Positive Survey Responses, }{ }^{\text {b,d }} \%\end{array}$} \\
\hline & $\begin{array}{c}\text { Administered } \\
\text { Immediately After June } \\
2015 \text { PREP }(\mathbf{n}=\mathbf{8 3})\end{array}$ & $\begin{array}{c}\text { Administered 6-12 } \\
\text { Months After June } 2015 \\
\text { PREP }(\mathrm{n}=53)^{\mathrm{e}} \\
\end{array}$ & $\begin{array}{c}\text { Administered } \\
\text { Immediately After June } \\
2016 \text { PREP }(\mathbf{n}=\mathbf{8 0})\end{array}$ & $\begin{array}{c}\text { Administered 6-12 } \\
\text { Months After June } 2016 \\
\text { PREP (n=75) }\end{array}$ \\
\hline $\begin{array}{l}\text { Anatomy/ } \\
\text { Physiology }\end{array}$ & 96 & 57 & 90 & 76 \\
\hline $\begin{array}{l}\text { Medical } \\
\text { Terminology }\end{array}$ & 100 & 65 & 91 & 83 \\
\hline Chemistry & 85 & 57 & 71 & 67 \\
\hline Microbiology & 95 & 53 & NA & NA \\
\hline Calculations & 87 & 55 & NA & NA \\
\hline $\begin{array}{l}\text { Q\&A } \\
\text { Upperclassmen }\end{array}$ & 95 & NA & 98 & 79 \\
\hline Curriculum & 93 & NA & 95 & 85 \\
\hline $\begin{array}{l}\text { Avoiding } \\
\text { Plagiarism }\end{array}$ & 98 & 44 & 96 & NA \\
\hline Professionalism & 93 & 45 & 95 & NA \\
\hline Citing Resources & 94 & 43 & NA & NA \\
\hline $\begin{array}{l}\text { Time } \\
\text { Management }\end{array}$ & 95 & 50 & 93 & NA \\
\hline Critical Thinking & 94 & 43 & 93 & NA \\
\hline Mentor-mentee & 93 & NA & 91 & NA \\
\hline $\begin{array}{l}\text { Student Support } \\
\text { Services }\end{array}$ & 99 & NA & NA & NA \\
\hline $\begin{array}{l}\text { Skills Case } \\
\text { Studies }\end{array}$ & 100 & NA & NA & NA \\
\hline Cultural Diversity & NA & NA & 91 & NA \\
\hline Co-curriculum & NA & NA & NA & 77 \\
\hline $\begin{array}{l}\text { Leadership/ } \\
\text { Teamwork }\end{array}$ & NA & NA & NA & 80 \\
\hline Mentor-Mentee & NA & NA & 91 & 64 \\
\hline
\end{tabular}

Abbreviations: PREP = pharmacy readiness and enrichment program; $\mathrm{NA}=$ not applicable

${ }^{\text {a }}$ Sessions that did not appear in a PREP curriculum and/or in a survey are indicated as NA

${ }^{\mathrm{b}}$ Positive student perceptions (eg, good, very good, and excellent) were grouped together and summed

${ }^{\mathrm{c}}$ Sum of positive student perceptions for 10 sessions that appeared in a survey administered immediately after PREP was greater than in a survey administered 6-12 months after PREP, $p<.001$

${ }^{\mathrm{d}}$ Sum of positive student perceptions for six sessions that appeared in a survey administered immediately after PREP was greater than in a survey administered 6-12 months after PREP, $p<.01$

${ }^{\mathrm{e}}$ Sum of positive student perceptions for the first five scientific sessions was greater than for the last five non-scientific sessions, $p<.05$

\section{DISCUSSION}

The first objective of this research was to describe the SCSOP pre-matriculation program and its development process. The SCSOP PREP can generally be divided into four types of sessions: brief reviews of scientific content, instruction on cognitive and affective skills, introduction of key professionalism concepts related to pharmacy, and professional/personal interactions between student pharmacists and faculty members (Table 1). Scientific content sessions briefly review key topics/concepts from prerequisite courses that may help the students identify where they may need to spend more time reviewing and preparing for certain courses or topics within their first professional year. Sessions on cognitive and affective skills (ie, attention to detail, critical thinking, time management, and organization) are critical to student success in the pharmacy curriculum, life-long learning, and their development of entrustable professional abilities. Sessions on professionalism (eg, email communication, etiquette, cultural awareness, and avoiding plagiarism) introduce students to key concepts related to pharmacy as a profession and to work as part of an interprofessional 


\section{American Journal of Pharmaceutical Education 2019; 83 (7) Article 7021.}

Table 5. Model for a Pre-matriculation and Enrichment Program to Prepare Students Beginning a Doctor of Pharmacy Program ${ }^{\mathrm{a}}$

\begin{tabular}{|c|c|c|c|c|}
\hline Transitional Sessions & $\begin{array}{l}\text { Professionalism/ } \\
\text { Ethics }\end{array}$ & $\begin{array}{l}\text { Scientific/Focused } \\
\text { Topic Review }\end{array}$ & $\begin{array}{c}\text { Group Interactions/Affective } \\
\text { Domain }\end{array}$ & $\begin{array}{c}\text { Higher Order/ } \\
\text { Cognitive } \\
\text { Domain }\end{array}$ \\
\hline \multicolumn{5}{|l|}{ Pre-matriculation } \\
\hline $\begin{array}{l}\text { Time management/ } \\
\text { organization }\end{array}$ & $\begin{array}{l}\text { Professional } \\
\text { communication } \\
\text { skills }\end{array}$ & $\begin{array}{l}\text { Anatomy \& } \\
\text { Physiology }\end{array}$ & $\begin{array}{l}\text { Q\&A or social interaction with } \\
\text { upper-classmen and/or alumni }\end{array}$ & Attention to detail \\
\hline Academic support services & Cultural diversity & $\begin{array}{l}\text { General chemistry \& } \\
\text { Organic chemistry }\end{array}$ & Team work/building & $\begin{array}{l}\text { Mindfulness/ } \\
\text { awareness }\end{array}$ \\
\hline \multirow[t]{3}{*}{$\begin{array}{l}\text { Learning styles/Myers- } \\
\text { Briggs type indicator }\end{array}$} & $\begin{array}{l}\text { Social media } \\
\text { footprint }\end{array}$ & $\begin{array}{l}\text { Math-1: Preparation } \\
\text { for calculations }\end{array}$ & Importance of leadership & \\
\hline & $\begin{array}{l}\text { Dress code/ } \\
\text { etiquette }\end{array}$ & Medical terminology & Self-awareness & \\
\hline & & Immunology & & \\
\hline \multicolumn{5}{|l|}{ First Professional Year ${ }^{\mathrm{b}}$} \\
\hline Test-taking and study skills & $\begin{array}{l}\text { Identifying and } \\
\text { avoiding } \\
\text { plagiarism }\end{array}$ & Biostatistics & Mentor \& mentee meetings & $\begin{array}{l}\text { Critical thinking/ } \\
\text { problem solving }\end{array}$ \\
\hline Stress management & Preparing for IPPE & Microbiology & $\begin{array}{l}\text { Co-curriculum \& associated } \\
\text { activities }\end{array}$ & $\begin{array}{l}\text { Skills for solving } \\
\text { case studies }\end{array}$ \\
\hline $\begin{array}{l}\text { Accessing, citing, and } \\
\text { using health care } \\
\text { resources }\end{array}$ & $\begin{array}{l}\text { White coat } \\
\text { ceremony }\end{array}$ & $\begin{array}{l}\text { Math-2: Preparation } \\
\text { for } \\
\text { pharmacokinetics }\end{array}$ & Interprofessional education & \\
\hline $\begin{array}{l}\text { Scientific/professional } \\
\text { writing skills }\end{array}$ & & & & \\
\hline
\end{tabular}

Abbreviations: IPPE = introductory pharmacy practice experience

${ }^{a}$ Sessions are listed in order of importance under each section. Selection according to allowed time and preference for school's objective

${ }^{\mathrm{b}}$ These sessions can be placed strategically throughout the first-year curriculum according to when it best correlates with delivery of relevant material in school's curriculum

health care team. While these concepts are discussed in courses during the first professional year and beyond, it appears important that students encounter these topics before they matriculate into the pharmacy program at SCSOP.

The ACPE Standards 2016 place a greater emphasis on the affective domain skills of student pharmacists and being able to provide content and assessment of these skills in student pharmacists. ${ }^{15}$ The additional elements in the Standards that the SCSOP program was intended to address included leadership, innovation, entrepreneurship, and self-awareness in the student pharmacist. Therefore, changes introduced into the PREP administered in 2016 to the class of 2019 placed more emphasis on these skills, personal development, and professionalism. With these additional topics, some of the sessions took place during the orientation week and others were strategically placed throughout quarters one through three of the first professional year of the pharmacy program.

The University of North Carolina Eshelman School of Pharmacy requires their incoming student pharmacists to complete a pharmacy bridging course prior to matric- ulation. Their three-week intensive course is focused on presenting foundational knowledge in five scientific topics, applied math, biochemistry, biostatistics, organic chemistry, and physiology, to provide an even playing field to prepare students for the professional curriculum. ${ }^{18}$ In contrast, the objective of the SCSOP PREP is to provide a broad-spectrum introduction to the pharmacy professional curriculum that includes science topic reviews, professionalism, leadership, and affective skills development. Thus, the scientific review sessions differ from those at University of North Carolina as they are geared to remind students of major concepts and help guide them in their self-directed learning. Students have consistently appreciated these short scientific review sessions in PREP (Table 4).

When examining programs in medicine, which also has a challenging curriculum, there is a long history of pre-matriculation programs. ${ }^{19-21}$ Most schools of medicine offer pre-matriculation programs, which usually last from three to seven weeks. ${ }^{20,23-28}$ These medical pre-matriculation programs also differ in their aims, scope (eg, basic science enrichment, study skills 


\section{American Journal of Pharmaceutical Education 2019; 83 (7) Article 7021.}

acquisition), and targeted student population. $.^{20,22-28} \mathrm{Be}-$ cause the programs are substantially different, the outcomes also vary, with some programs reporting positive academic outcomes while others do not. ${ }^{19,20,21,26}$ Pre-matriculation programs sometimes result in a boost in the confidence of their participants in their readiness for medical school. ${ }^{20}$ An interesting study showed that even a two-day (16 hours) simulation-based boot camp prior to internal medicine residency aimed to enhance specific skills, such as physical examination techniques and communication with patients and families, can result in significantly better performance in each of the simulated skills. ${ }^{29}$ Similar to prematriculation programs in schools of medicine, there are many opportunities to implement a wide variety of pre-matriculation programs in schools of pharmacy to enhance students' readiness and confidence.

The second objective of this study was to assess and describe student perceptions of PREP and its individual components. Student perceptions regarding the PREP sessions declined in surveys administered six or more months after completing PREP in comparison to those administered immediately following PREP (Table 4). The decline in students' positive perceptions of the PREP topics that appeared in both surveys for the class of 2019 was relatively minor, with an average decline of $14 \%(\mathrm{SD}=7 \%)$. The decline in students' positive perceptions regarding the topics that appeared in both surveys for the class of 2018 was larger at $42 \%$ $(\mathrm{SD}=9)$. A potential reason for these observations is that after six or more months of extensive course work, the students may not have remembered the details of the PREP sessions, and it was therefore harder for them to accurately recall and rate the value of those sessions. Possible reasons for the larger decline in student perceptions seen in the class of 2018 include differences in survey methodology used to assess the pre- and postmatriculation cohorts, and the use of focus groups for survey administration.

When surveys were administered soon after PREP students typically scored the chemistry/organic chemistry sessions lower than they scored other scientific sessions (Table 4). Because the lower ratings occurred consistently over several years, with different faculty members delivering the chemistry/organic chemistry PREP review session, we concluded the lower ratings were unrelated to the instructor who delivered this session. A rationale for the student perceptions may be associated to the fact that some of the student pharmacists do come to the program after having struggled in chemistry and organic chemistry courses during their undergraduate course work, and were anticipating challenges in the upcoming biochemistry course during the first quarter.
The third objective of this study was to identify measurable outcomes of academic performance to support implementation of the pre-matriculation program. There was no significant difference in the entering cumulative GPA or PCAT scores of the different cohorts (Table 2). Therefore, the significant differences seen in the cumulative GPAs at the end of first and second professional years for those cohorts who completed PREP compared to the control cohort supports the premise that PREP is a positive contributor to student success in the pharmacy program.

The final objective of this study was to outline a successful pre-matriculation program model that could be used by other schools of pharmacy. The model of the SCSOP PREP that started as an initial supplement to student orientation has transformed into a combined pre-matriculation and enrichment program suitable for the preparation of student pharmacists for their professional career in a changing health care environment. The key components of our pre-matriculation model are listed in Table 5. The model should be tailored to a program's institution, mission, and patient/student population. Consideration should also be given to the resources necessary to conduct a successful pre-matriculation program, including personnel, facilities, time, and finances. ${ }^{20}$

A limitation of the study was that PREP may not have been the sole contributor to the increased average cumulative GPA. Such an increase in GPA could also be attributed to changes to the curriculum or faculty, or to reasons that are yet to be identified. Another limitation is the variations in surveys used throughout the years, specifically, the different Likert scales that were used, differences in survey question phrasing, and mode of administration, ie, small focus groups versus one large group. While this may have affected the quantitative results, it does not appear to have had a large impact on the qualitative results. However, it does support the importance of good research design as well as thoughtful construction and administration of effective survey tools to improve outcomes and data analysis.

The PREP can serve as a model for schools of pharmacy that are considering the implementation of a prematriculation program, or that have a pre-matriculation program in place and are seeking to modify or update their program. The changes observed in student perceptions to PREP components will require additional follow through; for example, setting up focus group meetings to gather insight into what was helpful to the students and what students perceive as opportunities for improvement in the program. 


\section{American Journal of Pharmaceutical Education 2019; 83 (7) Article 7021.}

\section{CONCLUSION}

The SCSOP PREP is a relatively short pre-matriculation program, with its main components being curriculum overview and scientific content reviews, professionalism, time management, critical thinking, cultural diversity, and personal interactions. There was clear improvement in the average first professional year GPA and second professional year GPA of student pharmacists that participated in PREP compared to those who did not. It is possible to conduct a pre-matriculation program with a wide range of components even during a short time span. As shown for the class of 2019 PREP, it is also possible to deliver some PREP components during the first professional year of the pharmacy program rather than prior to matriculation.

\section{ACKNOWLEDGMENTS}

The authors thank Dr. James L. Schmidhammer, Senior Lecture Emeritus from the University of Tennessee at Knoxville, Haslam College of Business, Department of Business Analytics and Statistics, for statistical consultation. The authors also thank Drs. Jacob Dunbar and Eric Dadey from the Department of Pharmaceutical Sciences, South College School of Pharmacy for their constructive comments regarding the manuscript.

\section{REFERENCES}

1. Council of Deans Business Meeting Minutes, February 8, 2015, Austin, TX. Am J Pharm Educ. 2015;79(9):Article S19.

2. Council of Dean's Business Meeting, July 13, 2015, National

Harbor, MD. Am J Pharm Educ. 2015;79(9):Article S20.

3. Council of Deans Business Meeting, July 25, 2016, Anaheim, CA. Am J Pharm Educ. 2017;80(10):Article S26.

4. 2016 AACP Council of Deans Interim Business Meeting, February 21, 2016, Tampa, FL. Am J Pharm Educ. 2017; 80(10):Article S25.

5. Maine LL, Adams JL. Pharmacy is right for me. Am J Pharm Educ. 2015;79(10):Article 145.

6. Holdford DA. Is a pharmacy student the customer or the product? Am J Pharm Educ. 2014;78(1):Article 3.

7. Jeffres MN, Barclay SM, Stolte SK. Academic entitlement and academic performance in graduating pharmacy students. Am J Pharm Educ. 2014;78(6):Article 116.

8. Chisholm-Burns MA, Spivey CA, Jaeger MC, Williams J, George C. Development of an instrument to measure pharmacy student attitudes toward social media professionalism. Am J Pharm Educ. 2017;81(4):Article 65.

9. Klausner EA, Mark KS, Hamilton BS, Rowe EL. Orientation, boot camps, and pre-matriculation programs in schools of pharmacy. Am J Pharm Educ. 2017;81(5):Article S5.

10. Pre-Matriculation Summer Program (PPMSP). Xavier University of Louisiana College of Pharmacy. http://www.xula.edu/ cop/Current $\% 20$ Students/current-ppmsp.html. Accessed February 15, 2018.

11. Multicultural and Community Affairs - Pre-matriculation Programs. Creighton University Health Sciences. https:// healthsciences.creighton.edu/https $\% 3 \mathrm{~A} /$ healthsciences.creighton. edu/multicultural-and-community-affairs/pre-matric-program/pre. Accessed February 15, 2018.

12. Pathway to PharmD. University of Montana Native American Center for Excellence. http://health.umt.edu/nacoe/programs/P2PD/ default.php. Accessed February 15, 2018.

13. Learning Center - Prematriculation Program. Northeast Ohio Medical University. http:/www.neomed.edu/learningcenter/ prematriculation/. Accessed February 15, 2018.

14. Brownlee SP, Ralston G, Yocum A. Development of a proactive, comprehensive approach to support student academic success. Am J Pharm Educ. 2015;79(5):Article S4.

15. Accreditation standards and key elements for the professional program in pharmacy leading to the Doctor of Pharmacy degree ("Standards 2016"). Accreditation Council for Pharmacy Education. https://www.acpe-accredit.org/pdf/Standards2016FINAL.pdf. Accessed February 15, 2018.

16. The University of Iowa College of Pharmacy. PharmD Curriculum. https://pharmacy.uiowa.edu/prospective-students/ pharmd-program/pharmd-curriculum. Accessed February 15, 2018.

17. Doctor of Pharmacy Curriculum - PharmD Degree Requirements. https://pharmacy.uiowa.edu/students/professionalgraduate-programs/pharmd-programs/doctor-pharmacy-curriculum. Accessed February 15, 2018.

18. McLaughlin JE, Khanova J, Persky A, Hathaway N, Cox W. Design, implementation, and outcomes of a three-week pharmacy bridging course. Am J Pharm Educ. 2017;81(7):Article 6313.

19. Lu Y, Notebaert A. The impact of the summer pre-matriculation program on student approaches to studying in gross anatomy course, Med Sci Educ. 2018;28(1):57-64.

20. Kornitzer B, Ronan E, Rifkin MR. Improving the adjustment of educationally disadvantaged students to medical school: the summer enrichment program. Mt Sinai J Med. 2005;72(5):317-321.

21. Hesser A, Lewis L. Evaluation of a summer prematriculation program for black and other nontraditional students. Acad Med. 1992;67(4):270-272.

22. Tucker RP. Performance in a prematriculation gross anatomy course as a predictor of performance in medical school. Anat Sci Educ. 2008;1(5):224-227.

23. Herling PJ, Mohseni BT, Hill DC, et al. Impact of anatomy boot camp on students in a medical gross anatomy course. Anat Sci Educ. 2017;10(3):215-223.

24. Richardson BL, Saffran M. Effects of a summer preview program of study skills and basic science topics on the academic performance of minority students. J Natl Med Assoc. 1985;77(6):465-471.

25. Williams MT. Pre-matriculation program at the University of South Florida College of Medicine. Acad Med. 1999;74(4):397-399. 26. Schneid SD, Apperson A, Laiken N, Mandel J, Kelly CJ, Brandl K. A summer prematriculation program to help students succeed in medical school. Adv Health Sci Educ Theory Pract. 2018, doi 10.1007/s10459-017-9808-8.

27. Miller CJ. Identification of a study skills program for entering atrisk medical students. Adv Physiol Educ. 2014;38:229-234.

28. Kosobuski AW, Whitney A, Skildum A, Prunuske A. Development of an interdisciplinary pre-matriculation program designed to promote medical students' self-efficacy. Med Educ Online. 2017;22(1):1272835.

29. Wayne DB, Cohen ER, Singer BD, et al. Progress toward improving medical school graduates' skills via a "boot camp" curriculum. Sim Healthcare. 2014;9(1):33-39. 